\title{
TWO CASES OF PLASMACYTOMA OF THE LOWER RESPIRATORY TRACT
}

\author{
BY \\ J. D. KENNEDY AND D. V. KNEAFSEY \\ From the Department of Pathology of University College and Regional Hospital, Galway, and \\ the Department of Thoracic Surgery, Regional Sanatorium, Galway
}

(RECEIVED FOR PUBLICATION JUNE 22, 1959)

Plasmacytoma arising in the lower respiratory passages is very rare, as most primary plasmacytomas of soft tissue arise in the upper respiratory passages as described in Hellwig's review (1943). The purpose of this report is to place on record two cases of primary plasmacytoma, in one case arising from the bronchus and in the other from the trachea just above the carina.

\section{CASE REPORTS}

CASE 1.-A youth, aged $17 \frac{1}{2}$ years, was admitted to the Regional Sanatorium, Merlin Park, in November, 1954, with a history of cough with

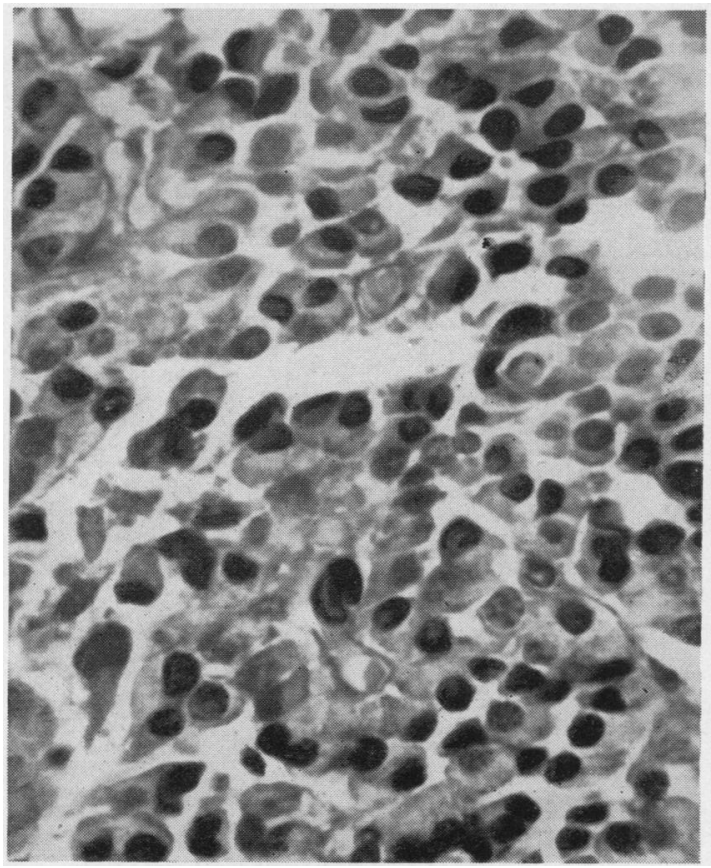

Fig. 1.-Photomicrograph of tumour from Case 1, showing it to be composed solely of plasma cells. Haematoxylin and eosin, $\times 500$. haemoptysis for two months. Radiography showed a collapsed middle lobe. On bronchoscopy a cherryred tumour was seen almost blocking the main bronchus at the level of the middle lobe. On November 25, 1954, the right middle and lower lobes were resected (D.V.K.). The resected specimen showed a pedunculated, rounded tumour filling the lower part of the main bronchus just above the orifice of the middle and lower lobe bronchi. The middle lobe showed well-marked collapse, with cylindrical bronchiectasis in both lobes.

Histologically, the tumour was covered by ulcerated bronchial mucosa and consisted entirely of plasma cells lying in a delicate reticulin framework (Fig. 1). Inflammatory cells were present close to the ulcerated surface. Resected lymph nodes were not involved.

The patient was recalled in July, 1956, nearly two years after operation. At that time he was in excellent health, blood count, marrow biopsy, and total serum protein level being within the normal range. His own doctor states that he continues in normal health.

CASE 2.-A man, aged 66 years, first noted shortness of breath in December, 1956. He was admitted to hospital in Clonmel in July, 1957, when bilateral apical pulmonary tuberculosis was found, with tubercle bacilli in the sputum. He was treated with streptomycin and $p$-aminosalicylic acid, but the breathlessness became worse and he was admitted to Ardkeen Chest Hospital in October, 1957. On bronchoscopy (Mr. Hickey) a rounded tumour was seen completely filling the lumen of the trachea about 1 in. $(2.5 \mathrm{~cm}$.) above the carina. This was removed through the bronchoscope, the biopsy being reported as a plasmacytoma. The site of origin was cauterized three weeks later. On January 9, 1958, the tumour was observed to have recurred. On this occasion right thoracotomy, through the bed of the fourth rib, was carried out. The tumour was resected with an ellipse of trachea around it. A pulsion diverticulum which had occurred above the tumour was also dealt with.

The patient has progressed well. His sputum was negative for tubercle bacilli, and the tumour had not visibly recurred by April, 1958. 
The specimen consisted of an oval pedunculated tumour superficially ulcerated, measuring $2 \mathrm{~cm}$. by $1 \mathrm{~cm}$., arising from a resected ring of trachea by means of a pedicle (Fig. 2). Histologically, it was covered by tracheal epithelium showing squamous metaplasia. The tumour consisted entirely of mature plasma cells, having in places a pseudo alveolar arrangement (Fig. 3). Lymph nodes resected were not

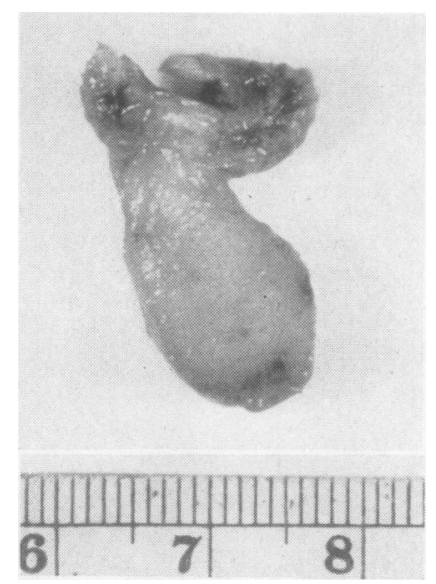

FIG. 2.-Resection specimen from Case 2 from just above the carina. Scale in centimetres.

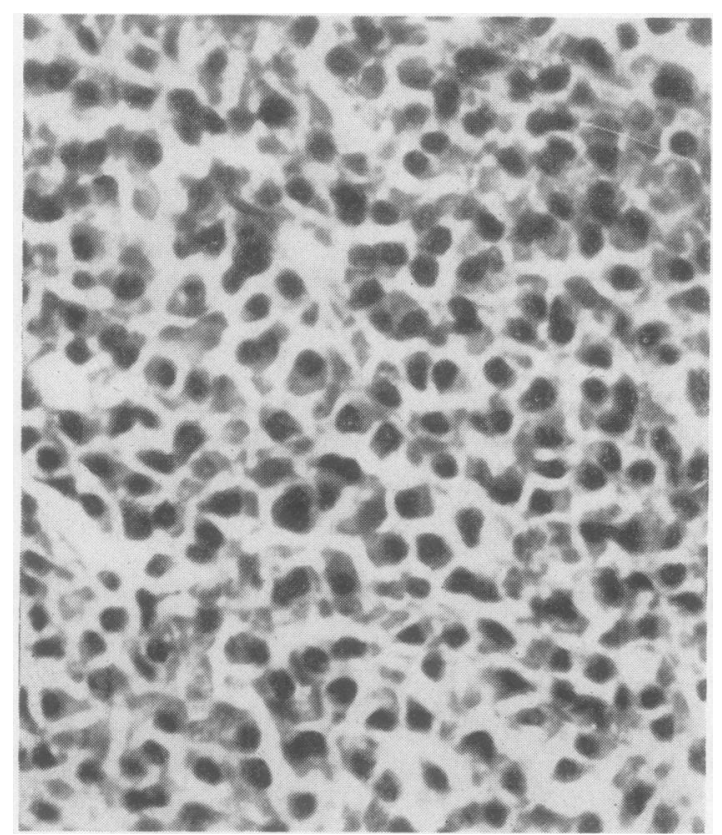

Fig. 3.-Photomicrograph of tumour from Case 2, showing tumour again composed solely of plasma cells. Haematoxylin and eosin, $\times 350$. involved. Electrophoresis of the serum proteins after operation showed no abnormal globulin. Theo total protein was $6.7 \mathrm{~g} . / 100 \mathrm{ml}$., of which $3.56 \mathrm{~g}$. was albumin, 0.45 g. $\alpha$ globulin, 0.64 g. $\alpha_{2}$ globulin,, $\bar{Q}$ 0.72 g. $\beta$ globulin, and 1.33 g. $\gamma$ globulin.

A review of this patient in October, 1958, 1005 months after resection, showed no evidence of local $\vec{\circ}$ recurrence on bronchoscopy. Examination of urineand serum remained negative for myeloma globulin. $\vec{\omega}$

\section{Discussion}

Neoplastic plasmacytoma is distinguished from $\vec{f}$ plasma cell granuloma by being composed solely $\stackrel{+}{-}$ of plasma cells, to the exclusion of all others save for the fibrovascular stroma. The granuloma has $\omega$ an admixture of other types of inflammatory cells $?$ among the preponderant plasma cells. . Both tumours described here fulfil the definition of

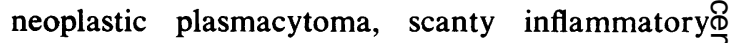
cells being seen only in the superficially ulcerated픙 areas. Reports of similar tumours are scanty. $\stackrel{\mathbb{D}}{-}$ Gordon and Walker (1944) described a case of $\overrightarrow{0}$ plasmacytoma in the lung which was treated by resection. Childress and Adie (1950) described $a$ plasma cell tumour of the mediastinum and lung.o This recurred nine years later (1955). Kuley and Kuntman (1951) and Cotton and Penido (1952) each described a plasmacytoma arising in the lung. Our two cases differ in that they were of bronchial 2 and tracheal origin respectively. Willis (1953) $\overrightarrow{\overrightarrow{0}}$ states that Hinz (1941) saw a plasmacytoma of a 3 main bronchus with local " amyloid" deposits. Liebow (1952), in a discussion of benign intrabronchial tumours, states that a plasmacytoma has been described, but quotes no reference. Grant and Ross (1958) described a case in which thex tumour was multiple and occurred in the lowero trachea. The tumour masses were not observed to increase in size during a period of almost threeO years, and were subsequently not influenced by radiotherapy. These authors reviewed the literature, giving references to six cases of plasmad cell tumour involving the trachea, including the case of Hinz (1941) already quoted.

Though the tumours in our two present cases were benign histologically and appeared localized, the prognosis must remain uncertain. It is well $\omega$ known that soft tissue plasmacytoma may subse? quently become generalized even after longe intervals of quiescence. Dolin and Dewar (1956)迎 analysed 161 cases of extramedullary plasma-? cytoma published in the literature from 1905 to 1953. Of 82 patients followed for one to fouro years, $42.7 \%$ were alive and free of disease. Of@ 27 patients followed five to 10 or more years, $\Omega$ $55.6 \%$ were alive and free of disease. 


\section{SUMMARY}

Two cases of neoplastic plasmacytoma of the lower respiratory tract are described. In one case the tumour arose from the lower part of the right main bronchus. Recurrence or dissemination has not occurred four years after resection. In the other case the tumour arose from the trachea immediately above the carina; local resection has not been followed by recurrence or dissemination 10 months later.

\section{REFERENCES}

Childress, W. G., and Adie, G. C. (1950). J. thorac. Surg., 19, 794. (1955). Ibid., 29, 480.

Cotton, B. H., and Penido, J. R. F. (1952). Dis. Chest, 21, 218.

Dolin, S., and Dewar, J. P. (1956). Amer. J. Path., 32, 83.

Gordon, J., and Walker, G. (1944). Arch. Path. (Chicago), 37, 22.

Grant, I. W. B., and Ross, J. D. (1958). Brit. J. Dis. Chest, 52, 299.

Hellwig, C. A. (1943). Arch. Path. (Chicago), 36, 95.

Hinz, W. (1941). Frankfurt. Z. path., 55, 509.

Kuley, M., and Kuntman, O. (1951). Dis. Chest, 19, 227.

Liebow, A. A. (1952). Atlas of Tumor Pathology, Section 5, Fascicle 17. Tumors of the Lower Respiratory Tract. Armed Forces Institute of Pathology, Washington, D.C.

Willis, R. A. (1953). Pathology of Tumours, 2nd ed. Butterworth, London. 